\title{
Geologic environments for nuclear waste repositories
}

\author{
Evan K. Paleologos ${ }^{1, *}$, Abdel-Mohsen O. Mohamed ${ }^{2}$, and Kosmas Pavlopoulos ${ }^{3}$ \\ ${ }^{1}$ Dept. of Civil Engineering, Abu Dhabi University, Abu Dhabi, United Arab Emirates \\ ${ }^{2}$ Assoc. Provost \& Chief Academic Officer, Zayed University, Abu Dhabi, United Arab \\ Emirates ${ }^{3}$ Dept. of Geography and Planning, Paris Sorbonne University-Abu Dhabi, United Arab \\ Emirates
}

\begin{abstract}
High-level radioactive waste (HLW) results from spent reactor fuel and reprocessed nuclear material. Since 1957 the scientific consensus is that deep geologic disposal constitutes the safest means for isolating HLW for long timescales. Nuclear power is becoming significant for the Arab Gulf countries as a way to diversify energy sources and drive economic developments. Hence, it is of interest to the UAE to examine the geologic environments currently considered internationally to guide site selection. Sweden and Finland are proceeding with deep underground repositories mined in bedrock at depths of $500 \mathrm{~m}$, and $400 \mathrm{~m}$, respectively. Equally, Canada's proposals are deep burial in the plutonic rock masses of the Canadian Shield. Denmark and Switzerland are considering disposal of their relative small quantities of HLW into crystalline basement rocks through boreholes at depths of $5,000 \mathrm{~m}$. In USA, the potential repository at Yucca Mountain, Nevada lies at a depth of $300 \mathrm{~m}$ in unsaturated layers of welded volcanic tuffs. Disposal of low and intermediate-level radioactive wastes, as well as the German HLW repository favour structurally-sound layered salt stata and domes. Our article provides a comprehensive review of the current concepts regarding HLW disposal together with some preliminary analysis of potentially appropriate geologic environments in the UAE.
\end{abstract}

\section{Introduction}

Two lines of defense are always used for land disposal of radioactive waste. The first and most important is the geologic setting, which is selected so that it would facilitate the operation of the disposal facility and in case the engineering measures fail it will contain or retard the spread of radioactive waste. Site selection includes low seismicity and low volcanic activity, geologic environments that would exclude faults or extensive fracturing, geochemical conditions that would hinder or retard the corrosion of containers, hydrologic setups of low precipitation and deep water table that would minimize water infiltration and fluid transport of the waste in case of failure, etc. More general considerations also include

\footnotetext{
${ }^{*}$ Corresponding author: evan.paleologos@adu.ac.ae
} 
distances from population centers, a simple legal framework of the repository area (preferably to be owned directly by the national government, rather than by a state or a municipality), low political representation, relative ease of access, etc.

Engineered barrier systems are constructed in order to: (a) isolate the waste from the biosphere for extremely long periods of time, (b) ensure that in case of failure contaminants migrating from the waste canisters will be of low concentration compared to natural background levels, and (c) provide assurance that any risk from inadvertent human intrusion would be minimal. Ensuring that engineered barrier systems will perform according to design criteria requires integration of site characterization data, waste and engineering properties' characteristics, in situ and laboratory testing, and modeling [1].

\section{The international experience on HLW repositories}

High-level radioactive waste results in two ways:

a. Spent reactor fuel, which is the fuel used in commercial nuclear reactors after it is no longer efficient in producing electricity, because the fission process has slowed down,

b. Reprocessed nuclear material for defense purposes. This waste in United States exists in Hanford, Washington, and Savannah River Site, South Carolina.

Despite ideas about HLW disposal in ocean trenches and the marine environment [2], or to the outer space, the scientific consensus of the last sixty years is that deep geologic disposal constitutes the safest means of isolating this type of waste for long timescales [3]. Efforts to identify locations for the permanent sitting of HLW have been in progress, among others, in USA, Sweden, Belgium, China, Finland, France, Germany, Japan, Russia, Switzerland, Canada, Italy, Mexico, the Netherlands, Taiwan, South Korea, Spain, and the UK. It must be kept in mind that, for any site selected, there will always exist significant uncertainty in a repository's performance since HLW containment and repository safety is mandated for tens of thousands of years (in the case of USA for one million years) and scientific predictions at such time scales are highly speculative.

Different types of geologic environments have been studied in various countries [27]. Sweden and Finland are proceeding with construction of deep underground repositories mined in bedrock at depths of $500 \mathrm{~m}$, and $400 \mathrm{~m}$ respectively [4, 5]. Countries, such as Denmark and Switzerland, having smaller quantities of HLW are considering disposal into crystalline basement rocks through deep boreholes that would reach depths of about 5,000m [6]. The initial 1957 proposal by the National Research Council of the US National Academy of Sciences favored disposal in structurally-sound layered salt strata and domes, or abandoned salt mines because very little water passes through salt, and fractures are selfhealing due to the creep of salt, which is plastic [3]. Such locations have been in use in many countries for the disposal of low- (LLW) and intermediate-level (ILW) radioactive wastes, and this is the environment of the Waste Isolation Pilot Plant (WIPP) in USA for the disposal of defense transuranic wastes (long lived ILW), $650 \mathrm{~m}$ below ground level. The German national center under investigation for the disposal of HLW lies in a salt dome in Lower Saxony with the final decision to be reached by 2019 [7].

Belgium has its candidate site in a deep clay formation (referred to as Boom clay), where experiments have been conducted in an underground research laboratory (HADES) that includes access shafts and two galleries at a depth of 250m [8]. France accelerated its efforts for HLW disposal after the passage of its 1991 Waste Act that specified the creation of underground laboratories, and in 1998 the French government approved construction of a repository in clay formations in eastern France. The French radioactive waste disposal agency, ANDRA, was expected to apply for construction and operating license in 2014 [7]. 


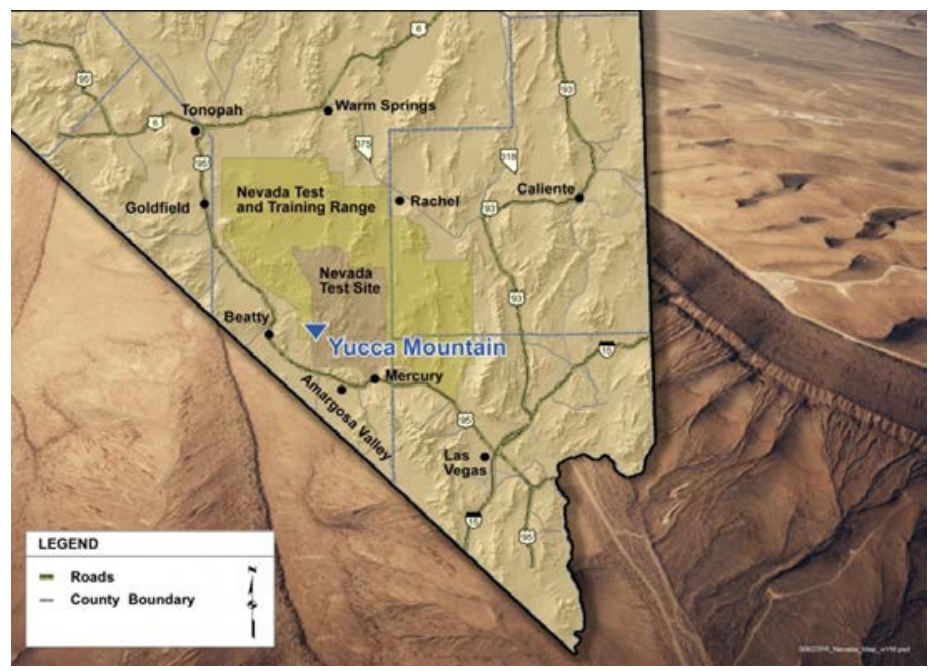

Fig. 1. Location of the potential US site for disposal of HLW at Yucca Mountain, Nevada (US DOE, http://energy.gov/photos/yucca-mountain).

In USA the Nuclear Waste Policy Act was amended in 1987 to designate the Yucca Mountain, Nevada (Fig. 1 and 2) as the sole site to be investigated as a US permanent repository for the country's 70,000 metric tons of HLW [7]. The potential repository would lie $300 \mathrm{~m}$ below ground surface and another $300 \mathrm{~m}$ above the underlying water table in unsaturated layers of welded volcanic tuff [9]. The site was selected because of its remoteness, its low-precipitation desert environment, its prior use as an underground testing facility of nuclear weapons, and because its land, part of the Nevada Test Site, belongs directly to the Federal government. The US Department of Energy's progress report to the US Congress on the study of the Yucca Mountain, as a potential HLW disposal site, is contained in the about 1,500 pages report "Viability Assessment of a Repository at Yucca Mountain," while supporting detailed scientific analyses are included in numerous reports and summarized in the even longer "Yucca Mountain Site Description" report $[10,11]$.

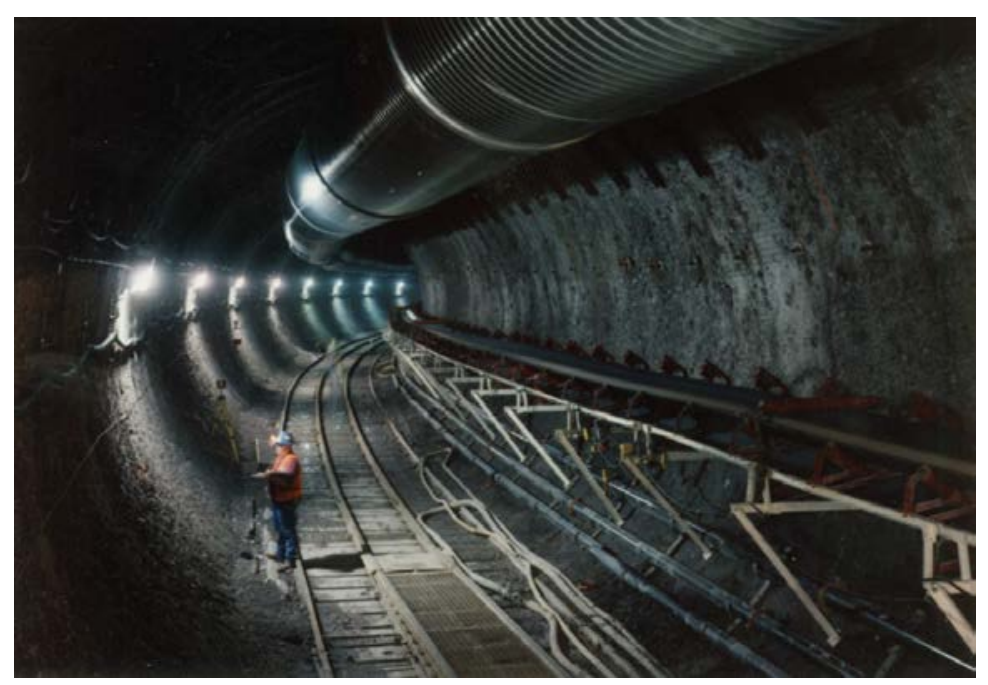

Fig 2. First curve of the main tunnel of the exploratory studies facility at Yucca Mountain, Nevada, October 1995. (US DOE, http://energy.gov/photos/yucca-mountain). 
The Yucca Mountain Project has met with delays and even cancellation in 2009 [12, 13]. However, in August 2013 the Federal Appeals Court ordered the US Nuclear Regulatory Commission (NRC) to resume its review of the DOE's application for a license to construct and operate the Yucca Mountain repository. In October 2014, the 781-page NRC report concluded that the 2008 license application by the U.S. Department of Energy (DOE) included "multiple barriers to isolate radioactivity from the environment" for hundreds of thousands of years, and hence the "repository design meets the requirements that apply after the repository is permanently closed" [14]. The US DOE's overall repository safety strategy lies in four tenets: (1) limited water contact with the waste packages, (2) long waste-package lifetime, (3) low radionuclide release rate from breached waste packages, and (4) reduction of radionuclide concentration during transport from breached waste packages. All four are meant to serve the US DOE's overall objective "to contain and isolate the radioactive wastes so that the dose impact to humans is attenuated to a relatively benign level" for a period of one million years [10].

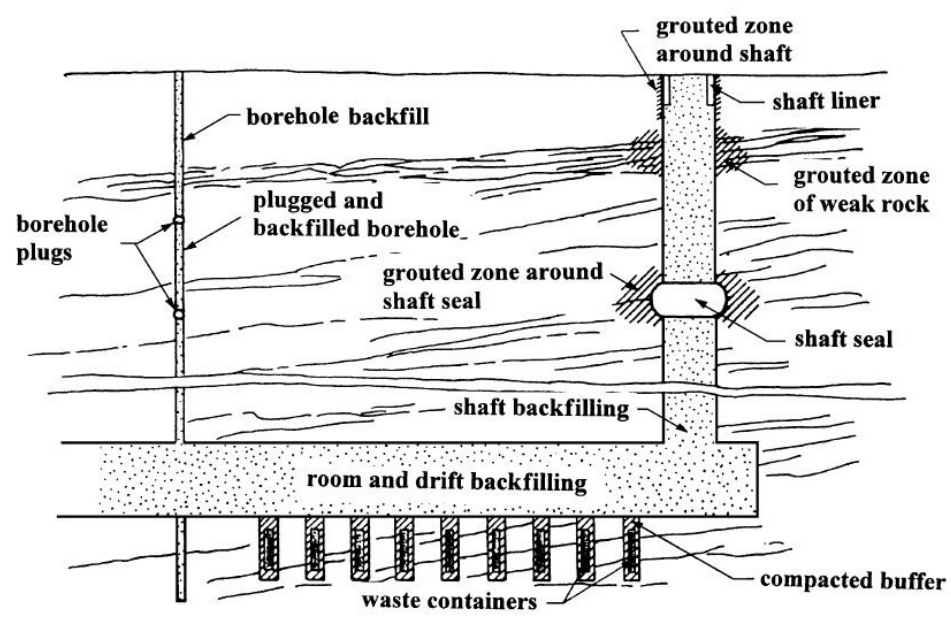

Fig. 3. Conceptual engineered barrier system in a deep rock repository in Canada [27].

The Canadian proposals, for the disposal of HLW concentrate on deep burial in the plutonic rock masses of the Canadian Shield [15]. Canadian concepts for deep disposal facilities identify several important components, intended to serve as both engineered and natural geologic barriers to long-term radionuclide migration. The vault system is constructed to a specific shape in a rock mass with known physical, mechanical, chemical, hydrogeological and tectonic characteristics. The rock mass serves as the primary natural, geologic barrier for radionuclide migration. The primary engineered barrier involves the sealed cylindrical containers that house the heat-emitting radioactive waste. The primary engineered geological barrier is a highly dense mixture of bentonite clay and crushed quartz sand within which the waste containers are emplaced. This engineered clay barrier, which in its compacted state is also referred to as a "buffer'" is either compacted in situ, in emplacement boreholes that are drilled into the base of the galleries of the waste disposal vault system, or placed around the waste containers in pre-compacted units.

The use of bentonite clays as engineered geological barriers is advocated in many concepts put forward for deep disposal of HLW. The potential of bentonite clays to act as geochemical filters for the sorption of radionuclides is an important factor in their selection as an engineered geological barrier. It is expected that, no matter the precautions, radionuclide migration will occur eventually, as a result of the natural disintegration of the 
waste containers. Bentonite clay also acts as a buffer and can protect the canisters containing the spent fuel from corrosion, as well as from minor bedrock movement. The clay will gradually absorb moisture and by swelling and filling the space around it is expected to fill any fractures in the hosting geologic environment. Finally, if a canister develops cracks the clay buffer will prevent water from entering the canister [16-23].

The secondary engineered geological barrier is the backfill material that fills the major part of the waste disposal vault system. In addition, other engineered barriers, such as the backfilling of the access shafts and boreholes, the use of bulkheads for the shaft and borehole sealing, etc., form the complete system of engineered barriers intended to minimize the migration of radionuclides from the repository to the biosphere throughout the life of the radioactive waste. A conceptual description of the Canadian engineered barrier system and its components are shown in Fig.3.

\section{The geologic environment of the UAE}

One of the first steps for the determination and characterization of geologic formations as appropriate host environments for HLW disposal is the understanding of their origin and their classification in terms of their desirable properties for such a role.

\subsection{Structural geologic history}

The Arabian Peninsula consists of two main geologic provinces: (i) the Arabian Shield, as a paleo-geographic area to the west, composed mostly of Precambrian igneous and metamorphic rocks, which has remained a largely positive region since the Cambrian; and (ii) the Arabian Platform (that includes Qatar and the UAE) as a vast area to the east of the Arabian Shield, which has undergone periodic subsidence, and which has accumulated a sequence of sedimentary rocks ranging in age from Cambrian to recent geologic times.

The UAE is situated on the north-eastern margin of the Arabian plate. During the Early Mesozoic the area was situated near the southern margin of the large Tethys Ocean, which separated Eurasia to the north from the paleo-continent of Gondwana (Africa, Arabia, Australia and India) to the south. In the Triassic period rifting affected the paleo-continent of Gondwana, leading to the development of an ocean basin called Neo-Tethys. The majority of the rocks of the UAE were formatted within and on the margins of this basin. Closure of the Neo-Tethys occurred during the Late Cretaceous to Paleogene as Africa and Arabia moved northwards colliding with Eurasia. This event created the distribution of the rock units that are seen in the UAE, as well as many major structural features [24]. The geologic formations of the UAE can be divided into five main units [28]:

a. The Middle Permian-Lower Cretaceous carbonate platform sequence (Hajar Supergroup) is exposed in the northern part of the UAE, where it forms the high mountains of the Musandam peninsula.

b. The Late Triassic-Upper Cretaceous sequence of fine- to coarse-grained limestone turbidites and deep water sediments, dominated by mudstones and cherts with minor volcanic rocks and olistostrome deposits (Masafi-Hatta). They were folded and thrusted during the obduction of the ophiolites during the Upper Cretaceous [25].

c. The sequence of metamorphic rocks consisting of green schists, amphibolite schists, and meta-volcanic and meta-igneous formations (Masafi-Ismah-Bani Hamid).

d. The Upper Cretaceous UAE-Oman ophiolite that extends for over than $500 \mathrm{Km}$ through the mountains of northern Oman and the UAE (Hajar Mountains). The ophiolite was thrusted or obducted onto the margin of the Arabian continent during the closure of the Neo-Tethys in Upper Cretaceous. 
e. The Upper Cretaceous-Neogene formations that are exposed along the western edge of the Hajar Mountains and in outliers in the desert to the west.

f. The Quaternary formations that cover the above formations. Fluvial gravel depositions are well developed in the wadis passing into large-coalesced alluvial fans or bahadas along the mountains piedmonts. Sand dunes of various types overlap the oldest geological formations. Along the UAE coastlines a lot of coastal barriers, spits, lagoons have developed, with the locally existence of mangrove stands, bounded by sabkha flats.

\subsection{Tectonics and lithology}

Two main tectonic features had a deep influence on the structural evolution of Abu Dhabi: the central Arabian arch and the Rub al Khali basin. These two structures plunge gently towards the North east towards the Arabian Gulf. General thickening of sedimentation is observed in this direction indicating an increasing rate of subsidence.

Gentle and simple folds are common characteristics. The main fold axes directions in Abu Dhabi near the top of Thamama formations are N-S, E-W/NE-SW, and NW-SE. The "Arabian folds" aligned N-S is the most dominant and probably related to deep-seated basement tectonics. Diapiric salts are believed to underlie most of the structures of Abu Dhabi. Furthermore, in the western Abu Dhabi regions and islands there exist salt pierced structures, surrounded by Tertiary and Quaternary deposits associated with Cambrian sediments carried up by salt intrusions.

The Hajar Mountains, as we know them today, are the result of oogenesis during late Oligocene to early Miocene (ca. 30-20 million years ago), followed by uplift and erosion under generally arid or semi-arid conditions, continuing to the present day. This deformation and uplift are presumed to be related to the collision of the Eurasian plate with the Afro-Arabian plate and other marginal plates, coupled with the opening of the Red Sea. The Hajar Mountains, however, are situated relatively far from the relevant plate boundaries and no conceptual model has yet been proposed which fits this mid-Tertiary phase of activity into our evolving understanding of plate tectonics and its relationship to mountain building.

The surface geologic formations of UAE are covered by sand fields. Outcrops are confined only to Ras Al Khaima, Al Mleha and Al Madam area, and to the Al-Ain area to the East, where the Hajar Mountains form part of that region. Sand dune ridges reaching heights of $150 \mathrm{~m}$ inland and plain gravel areas exist into the inter-dune areas. Evaporate flats (sabkha) dominate the coastal plains, which extend more than $80 \mathrm{~km}$ southwards into the sand deserts. Consequently the geology of this area is based exclusively on subsurface information. Data from below the Permian is quite scarce, as only 3 wells have penetrated the Permian sequences of Abu Dhabi. Offshore Abu Dhabi the sedimentary section from the Upper-Permian to recent times has a maximum thickness of more than 5500m [26].

\subsection{Potentially appropriate environments}

In the Emirate of Abu Dhabi six geologic environments have been identified:

a. Hard fractured rock to surface, which includes carbonate rocks, schists, and the ophiolite complex;

b. Hard fractured rock overlain by relatively high-permeability sedimentary rocks in which advective transport dominates, as limestones;

c. Hard fractured rock overlain by a sedimentary rock sequence containing at least one significant low-permeability formation in which diffusion dominates solute transport; 
d. Evaporites;

e. The Carbonate host rock; and

f. Non-evaporitic rock with hypersaline groundwater.

According to the stratigraphic correlation of Abu Dhabi onshore wells from the Paleozoic to the recent era a number of groups have been identified consisting of carbonate (limestone-dolomite), shale limestone, and anhydrite. Two main groups below the deeper aquifer system are important for further investigation for radioactive waste geological repositories. Both are below the shallow (160-460m) aquifer system and the deepest one (from 700 to $1600 \mathrm{~m}$ ) are represented in the onshore structural cross section of ADCO's fields shown in Fig. 4.

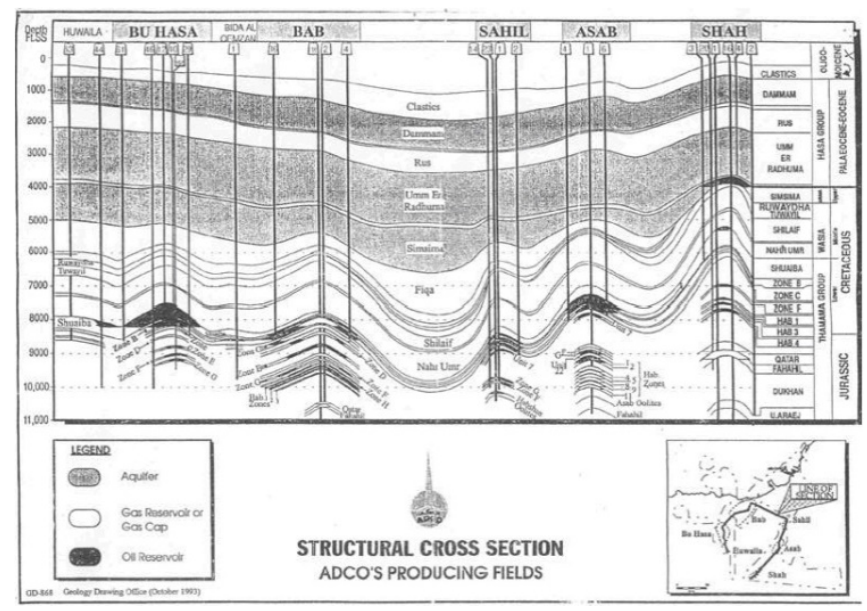

Fig. 4. Structural cross section ADCO's producing fields [26].

The first one is part of the deeper formation of the Bab-Agrab- Nahr Umr group of Middle Cretaceous era. This formation thickens gradually from about $75 \mathrm{~m}$ in the north to a maximum of $200 \mathrm{~m}$ in the south and southwest. It thins to approximately $100 \mathrm{~m}$ in the extreme east of the offshore area towards the Northern Emirates, in various depths between 2600-3000m approximately. The Nahr Umr formation consists of a sequence of shales with some rare sand lenses, glauconitic silts, and occasional beds of limestone, mostly packstones and wackestone.

The second one belongs to the Ruwais-Fiqa formation of the Upper-Cretaceous. It is a deep open marine-shelf environment deposit that ranges in thickness from $120 \mathrm{~m}$ to more than $360 \mathrm{~m}$ in offshore Abu Dhabi, in depths between 2000-2500m approximately. Its lower part consists of soft marl, calcareous shales, and argillaceous limestone and grades upwards into mainly argillaceous lime-wackestone.

\section{Summary and conclusions}

In this paper we have highlighted the different geologic environments and methods adopted by various countries for the disposal of high-level radioactive waste. Further, we have discussed the nature of the geological environment in UAE to outline the issues associated with the geologic formations in the country. Due to the nature of fractured rocks of the geologic formations, more investigations are required to be able to identify the suitability of sites. For example, cross-hole investigation can be used to develop and test geophysical and hydraulic methods and instruments for the purpose of detecting and mapping fracture 
zones. Also, electromagnetic (radar), seismic, and hydraulic (sinusoidal) techniques are well developed and tested, and could be used for such investigations. It is worth noting that a disturbance, such as a fracture zone, will affect the chemical and hydraulic transmission properties that would impact on the overall safety of the designed engineered barrier systems for the containment of radioactive wastes.

\section{References}

1. T. Avanidou, E. K. Paleologos, Water Resour. Research, 38, 11 (2002)

2. U.S. Academy of Sciences-National Research Council, Radioactive waste disposal into Atlantic and Gulf coastal waters; a report from a working group of the committee on oceanography of the National Academy of Sciences-National Research Council, 48 (1959)

3. National Research Council, The disposal of radioactive waste on land, 146 (1957).

4. SKB (Swedish Nuclear Fuel and Waste Management Company), Long-term safety for the final repository for spent nuclear fuel at Forsmark, TR-11-01, 3 vol. (SKB, Sweden, (2011)

5. POSIVA OY, Safety case for the disposal of spent nuclear fuel at OlkiluotoPerformance assessment 2012 (POSIVA 2012-04, Finland, 2013)

6. P. Brady, B. Arnold, S. Altman, P. Vaughn, Sandia Report SAND2012-7789, 30 (Sandia, September 2012)

7. National Research Council, Disposition of high-level waste and spent nuclear fuel: The Continuing societal and technical challenges, Committee on disposition of high-level radioactive waste through geological isolation, Board on Radioactive Waste Management, 212 (US National Academies Press, 2001)

8. ONDRAF/NIRAS (Belgian Agency for Radioactive Waste and Enriched Fissile Materials), Waste plan for the long-term management of conditioned high-level and/or long-lived radioactive waste and overview of related issues, NIROND 2011-02, (ONDRAF/NIRAS, Belgium, 2011)

9. US DOE, Assessment of disposal options for DOE-managed high-level radioactive waste and spent nuclear fuel, 32 (US DOE, October 2014)

10. US DOE, Viability assessment of a repository at Yucca Mountain, 5 Volumes and Overview (US DOE, Office of Civilian Radioactive Waste Management, 1998)

11. US DOE, Yucca Mountain Site Description, Yucca Site Characterization Project, draft A, 3 books (US DOE, Office of Civilian Radioactive Waste Management, Apr. 1998)

12. US DOE, Analysis of the total system life cycle cost of the Civilian Radioactive Waste Management Program, Fiscal Year 2007 (July 2008), DOE/RW-0591 (US DOE, Office of Civilian Radioactive Waste Management, 2008)

13. US DOE, Yucca Mountain repository license application, DOE/RW-0573, Rev.1. (US DOE, Office of Civilian Radioactive Waste Management, 2008)

14. US NRC (United States Nuclear Regulatory Commission), Safety evaluation report related to disposal to high-level radioactive wastes in a geologic repository at Yucca Mountain, Nevada. Volume 3: repository safety after permanent closure, NUREG 1949-Vol. 3, 781 (US NRC, October 2014)

15. L.H. Johnson, D.M. LeNeveau, D.W. Shoesmith, D.W. Oscarson, M.N. Gray, R.J. Lemire, C. Garisto, The disposal of Canada's nuclear fuel waste: The vault model for post closure assessment, AECL-1071, COG-93-4 (AECL Research Report, 1994)

16. R.N. Yong, A.M.O. Mohamed, D.M. Xu, Eng. Geol., 28, 315-324 (1990)

17. R.N. Yong, A.M.O. Mohamed, I. Shooshpasha, C. Onofrei, Eng. Geol., 47, 351-365 (1997) 
18. A.M.O. Mohamed, R.N. Yong, B.H. Kjartanson, C. Onofrei, Geotech. Test. J., GTJODJ, 19, 2, 155-163 (1996)

19. J. Graham, N.A. Chandler, D.A. Dixon, P.J. Roach, T. To, A.W.L. Wan, The buffer/container experiment: Volume 4-results, synthesis, issues, Review Report (Fuel Waste Technology, AECL, Whiteshell Labs, Canada, 1996)

20. J. Graham, J.M. Oswell, M.N. Gray, Can. Geotech. J., 29, 1033-1043 (1992)

21. J. Graham, F. Saadat, M.N. Gray, Eng. Geol., 28, 391- 403, (1990)

22. A.P.S. Selvadurai, Eng. Geol. 41, 219- 238 (1996)

23. Selvadurai, A.P.S., Special Issue of Eng. Geol., 47, 311- 317 (1997)

24. A.H.F. Robertson, M.P. Searle, in the Geology and Tectonics of the Oman Region, 49, 3-25 (Geological Society of London, Special Publication, 1990)

25. A.H.F. Robertson, A.E.D. Kemp, D.C. Rex, C.D. Blome, in the Geology and Tectonics of the Oman Region, 49, 285-305 (Geological Society of London, Special Publication, 1990)

26. F.N. Irani, Geology of the UAE, 143 (Schlumberger Drilling and Measurements, 2001)

27. A.M.O. Mohamed, E.K. Paleologos, D.N. Singh, V.G. Silvestre Rodrigues, Fundamentals of geo-environmental engineering, (Elsevier, to be published, 2017)

28. A.S. Alsharhan, A.E.M. Nairn, Sedimentary basins and petroleum geology of the Middle East, 843 and appendices (Elsevier, 2003) 